\title{
ラダ行音の構音発達についての研究
}

\begin{abstract}
大塚 登
要 約：幼児の構音発達において $/ \mathrm{r} /$ は $/ \mathrm{s}, \mathrm{dz}, \mathrm{ts} /$ とならんでもっとも獲得の遅れる音, $/ \mathrm{d} /$ は 比較的早期に獲得されるとされてきた. しかし, 小学校入学前後の子どもでは聴覚弁別能力の 未発達により $/ \mathrm{r} /$ と/d/の誤りは互いに密接に影響しあうため, 別個に考えるより同一の誤りと とらえるべきこと, 構音の誤りが書字にもあらわれるという報告もなされている. 本報告では 書字検査をもちいて小学校 1,2 年生におけるラ多行音の構音獲得の状態をしらべた. 1 年生 では 7 月では $7 \%+\alpha, 9$ 月では約 $6 \%, 2$ 年生では $4 \%$ のどもがまだ構音確立していないと いう結果をえた。同時に，構音確立したあるいは確立間近の群では検査語間の難易度により誤 答率に差が生じたが, 確立していない群では一様だった。検查語間の難易度と誤答率の関係か ら, 構音発達の予測の可能性が示唆された。
\end{abstract}

索引用語：ラダ行音, 書字検査, 構音発達

Research on Articulation Development of the Consonants in the $/ \mathrm{r} /$ and /d/ Series in Children

\section{Noboru Otsuka}

\begin{abstract}
Research on articulation development of $/ \mathrm{r} /$ has shown that more than $90 \%$ of children establish articulation by the latter half of their first 5 years, in the same way as with $/ \mathrm{s} /$, /ts/ and $/ \mathrm{dz} /$. Articulation of $/ \mathrm{d} /$ is normally established by about the latter half of the first 4 years.

Recently it has been reported that children who mispronounce $/ \mathrm{r} /$ as $/ \mathrm{d} /$ and $/$ or $/ \mathrm{d} /$ as $/ \mathrm{r} /$ confuse them also when writing. This paper undertakes an inquiry into $/ \mathrm{r} /-/ \mathrm{d} /$ problems based on the results of a writing test. This test was given to more than 500 children twice during first and once during second grade.

The results are as follows.

Slightly more than $7 \%$ of the children showed $/ \mathrm{r} /-/ \mathrm{d} /$ problems in July of first grade, down to about $6 \%$ in September. In May of second grade, $4 \%$ exhibited $/ \mathrm{r} /-/ \mathrm{d} /$ problems. The types of mistakes made on the test were different between this $4 \%$ group and the other children in the second grade. Namely, the other second graders made mistakes in words which contain both $/ \mathrm{r} /$ and $/ \mathrm{d} /$. This tendency did not appear in the $4 \%$ group.
\end{abstract}

Key words : /r/-/d/ problems, writing test, articulation development 


\section{はじめに}

構音発達研究では, $/ \mathrm{r} /$ は $/ \mathrm{s}, \mathrm{s}, \mathrm{dz}, \mathrm{ts} /$ とともに最も 遅く,/d/は比較的早期に確立する音とされる。船山 ら ${ }^{1)}$ は保育園児 90 人に絵カードを呼称させ, /r/は 4 歳後半で $60 \sim 79 \% ， 5$ 歳前半で $40 \sim 59 \%$ と変動が認 められるが最も遅れ, /d/ 4 歳後半で $100 \%$ 獲得す ると報告している. 中西ら ${ }^{2)}$ は幼児 1800 人に絵カード を呼称させ, $/ \mathrm{d} /$ は 4 歳前半に, $/ \mathrm{r} /$ は 5 歳後半に $90 \%$ の子どもで構音確立されるとしている。

頻度は少ないが誤る場合, $/ \mathrm{d} /$ は主に $/ \mathrm{r} /$ に置換され るという報告2)もある。が，早期に確立する音とされ， 問題になることはあまりなかった。

$/ \mathrm{r} /$ と/d/の誤りを関連づけて考えているのは馬瀬 ${ }^{3}$ である. 馬瀬は 28 人の 4 歳児を調べ, $/ \mathrm{r} / \rightarrow / \mathrm{d} /, / \mathrm{d} /$ $\rightarrow / \mathrm{r} /$ の誤りを指摘し，「ダ行・ラ行子音の混同」は語内 位置が影響すると報告した。語頭で $/ \mathrm{r} / \rightarrow / \mathrm{d} /$, 語中尾 で/d/ $/ \mathrm{r} /$ の誤りが目立つのは「語中では調音がゆる み, 語頭では調音がしまる」ためと考察している.

大塚 ${ }^{4}$ は就学時健康診断時の絵カード呼称による構 音検查で $9.1 \%(592$ 人中 54 人） $に / r / \rightarrow / d /, / d / \rightarrow$ $/ \mathrm{r} /$, あるいは $/ \mathrm{r} / \rightleftarrows / \mathrm{d} /$ の誤りが認められ, $/ \mathrm{r} /$ は先行 研究を支持するものの, /d/については独立に考える のではなく/r/と関連づけて考えるべきであり,/d/も 構音確立の最も遅れる音であるとし報告している。つ まり $/ \mathrm{d} /$ は $90 \%$ 前後の子どもでは比較的早期に確立

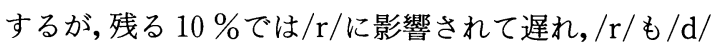
に影響されて構音確立が遅れると考えている。

細谷(5)り, Arndt, Shelton, Johnson, et al., 1977 ; Strange \& Broen, 1981 ; Broen, Strange, Doyle, et al., 1983 ; Hoffmann, Daniloff, Bengoa, et al., 1985 ; Shrinberg, Kwiatkowski, Best, et al., 1986 ; Rvachew \& Jamieson, 1989 は, 英語が母国語の機能的構 音障害児では $/ \mathrm{r} / \rightarrow / \mathrm{w} /$ がよく認められ, この両音の音 声知覚に関する報告を行っている. 筆者も $/ \mathrm{r} / \rightarrow / \mathrm{w}, \mathrm{v} /$ の子どもの経験が 1 例あるが, 日本語ではまれである と思われる。

遅れる原因として, 馬瀬の構音操作説に対して, 音 声的な要因を考える報告がある. 大塚( ${ }^{6}$ は未確立の 1 年生 21 人にテープレコーダーからの単音が/ $\mathrm{ra} /$ と きはライオンの/da/のときダイコンの絵をポインテ イングさせる方法で, 他者聴覚弁別ができていないこ とを報告している．松下ら》は行名行音の相互の置 換および歪みのみられる幼稚園児 32 人に無意味音節 の語音模唱訓練と聴覚弁別訓練を行い，両訓練とも構 音獲得に効果があったが, 特に聴覚弁別訓練が大きか
つたと報告している. 床井ら ${ }^{8)}$, 市川ら ${ }^{9} も$ 聴覚弁別に 着目した報告をしている. 正常な話し手の一時的な言

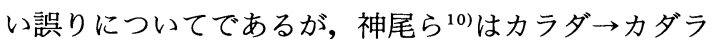
を音声素性の観点から, 文節音が交換されたのではな く, 両音が持つ素性のうちの「継続性」が交換された と考え,/r/の「継続性」が+からーにかわれば/d/とな り,一から+になれば/ $\mathrm{d} /$ が/ $/ \mathrm{r} /$ になると説明している.

ラレロ音とダデド音の誤りは書字にも出ることが報 告されている ${ }^{11}$. 原因は聴覚的に弁別できない子ども は 1 種類の音に 2 系統の文字があると理解するためと 考えられる. 音声素性の近似する弾音と破裂音の対立 では混同が好発するが, リル音とデヅ音は弾音と破擦 音であり構音面でも書字の面でも混同する率はずっと 少ない ${ }^{4,11)}$. 担任や親から当言語指導教室に紹介される 子どもたちは, ダクラ, ダクダ, ラクラ, ラクダのい ずれかを浮動的に言い, 浮動的に書く, という現象が 観察される. 固定して誤構音している場合でも書字は 浮動的であることが多い.

以下，本報告では「ラダ行音」といった場合は相互 に干渉するラレロ音とダデド音を意味するものとして 定義する.

構音検査は従来検査者の聴覚的印象にゆだねられて きた. ラダ行音を誤る子どもの構音は聴覚印象では, $/ \mathrm{r} / \rightleftarrows / \mathrm{d} /$ またはその中間音である. 聴覚判定ではどこ まで/r/または/d/の範疇で, どこまで中間音と判定す るのか検査者の主観に左右される.たとえば,「ダ・ン・ ゴ」という絵カードで「/ $\mathrm{ra} /$ と/da/の中間音・ン・ゴ」 という応答が得られたとき, / d/は早期に確立される という予見に影響されてしまう危険性が捨てきれな い.

書字検査では検査者の主観を判定から排除できる, また数量化することで, 重症度も測定できるという利 点がある.

構音獲得途上にある子どもは, 聴覚弁別能力の発達 と書字学習により構音確立が促される. 小学 1 年生で 混同していても 2 年生では誤りは軽減し, 聴覚弁別能 力も発達して, 構音確立したとみなせる子どもは少な くない.

大塚 ${ }^{12)}$ は書字検査中のラダ行混在語とその他の語の 誤りを, 被検児群と 1 年生の時点ですでに構音確立し たか確立間際の対照群と比較すると, 被検児群では他 の検査語とあまり変わらない誤答率であり対照群では 誤答率が高かった。その原因として, 対照群に含まれ る構音確立間際の子どもはラダ行音がそれぞれ単独で 現れるやさしい語では誤りが少なく, 混在語では $/ \mathrm{r} /$ と/d/の内的判断基準が相互干涉し混乱が生じるため 
誤りがふえる.ところが, 未確立群ではまだ内的判断 基準が形成されず，あてずっ洒うに記入するので検査 語間の難易度の差がなくなって一様な誤答率となるの ではないかと考えている.

その報告は逸脱值をとった子どものみ検査した結果 であるので， 2 年生の集団における書字検査の逸脱值 がわからないという不備があった。 1 年生の $6 \sim 7$ 月 ではこの書字検査の逸脱值は 5 であるが， 2 年生では 5 より小さくなることが予想される.

本報告では特殊学級在籍児をのぞく渋川市内の全 2 年生に書字検查を実施し, ラダ行音未確立児の出現率 を調べた。また，彼らの 1 年生のときの結果に，新し く書字検査を行った 1 年生の結果を加え, 小学校入学 後における出現率の変化に言及した。

なお，群馬県には博発方言などに認められるカロノ ウロンヤ（角のうどん屋）のような方言はない。

\section{検查}

1 年生だった 1995 年 7 月初旬に 516 人に書字検査 を行ったところ，逸脱值をとった子どもが 26 人いた。 そのうち 4 人は言語指導教室に通級し，転校した 1 人 をのぞく 21 人は特別な指導は受けずに 2 年生になっ た。

2 年生 518 人への検査は 1996 年 5 月中旬に, 新たな 1 年生 531 人には 1996 年 9 月中旬に実施した.いずれ も学級担任が実施した。

書字検査は大塚6,11,12)で使用した用紙から 5 語を差 し替えた（図 1 )。採点法は大塚 ${ }^{11}$ にしたがった。ただ し，ドナルドダックでドナルドロック，ヤサイサラダ でヤサイササラと答えた子どもがいたが，ともにラダ 行音の誤りとした。

\section{結＼cjkstart果}

棄却限界法 ${ }^{13)}$ をちいて，次式により誤答の棄却限 界域をもとめた。誤答分布の形状から上限のみを棄却 限界域とした。

$$
\begin{array}{ll} 
& \text { 上限・下限 }=\overline{\mathrm{x}} \pm \mathrm{u} \quad \sqrt{\frac{\mathrm{N}+1}{\mathrm{~N}} \mathrm{~F}_{0}} \\
\overline{\mathrm{x}} & \text { 誤答平均 } \\
\mathrm{N} & \text { 標本数 } \\
\mathrm{u} & \left.\mathrm{u}^{2} \text { (不偏分散 }\right)=\text { 標準偏差 } \\
\mathrm{F}_{0} & \mathrm{n}_{1}=1 \\
& \mathrm{n}_{2}=1 \\
&
\end{array}
$$

その結果，逸脱值は 1 年生の 7 月初旬では $5 ， 9$ 月 中旬でも 5,2 年生の 5 月では 3 になっていた（表 1 ).

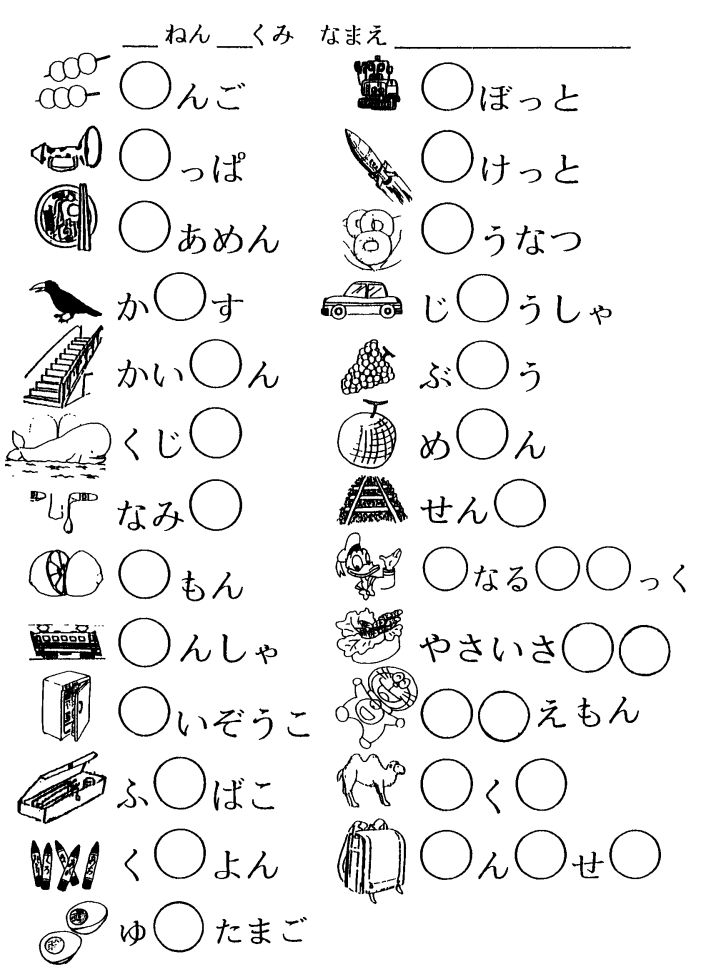

図 1 書字検査

表 1 棄却限界域の変化と逸脱值をとった児童

\begin{tabular}{lccc}
\hline & 1 年 7 月 & 1 年 9 月 & 2 年 5 月 \\
\hline 被検 児数 & 516 人 & 531 人 & 518 人 \\
誤 答 & 411 & 352 & 206 \\
誤 答平均 & 0.797 & 0.663 & 0.398 \\
標 準 偏 差 & 1.930 & 1.698 & 1.211 \\
棄却限 界 & 4.462 & 4.328 & 2.747 \\
逸 脱 值 & 5 & 5 & 3 \\
逸脱值をとった児童数 & 26 人 & 27 人 & 20 人 \\
出 現 率 & $5.0 \%$ & $5.1 \%$ & $3.9 \%$ \\
\hline
\end{tabular}

1 年生の 7 月の時点で 5 以上の逸脱値をとった子ど も（I, II, V群）は 26 人, 出現率 $5.0 \%$ でった。 3 以上の逸脱值をとった 2 年生 (II, III, IV群) は 20 人いた. 出現率 $3.9 \%$ であった. 1 年生のとき逸脱值 をとった 2 年生 25 人 ( I , II 群. 資料の不備な V 群は 除く）のうち 9 人は依然逸脱值をとっていた（II群）. また, 2 年生になって新たに逸脱值をとった子ども「III 群)も 9 人いた(表 2 ).この 18 人にIV群の 35 男 36 女 を加えた 20 人の性別は男児 16 人，女児 4 人であり有 意差が認められた $\left(\chi^{2}=6.55, \mathrm{df}=1, \mathrm{P}<0.05\right)$.

今回の検査語では, ラダ行音混在語はレッシャとい 
表 2 書字検査結果

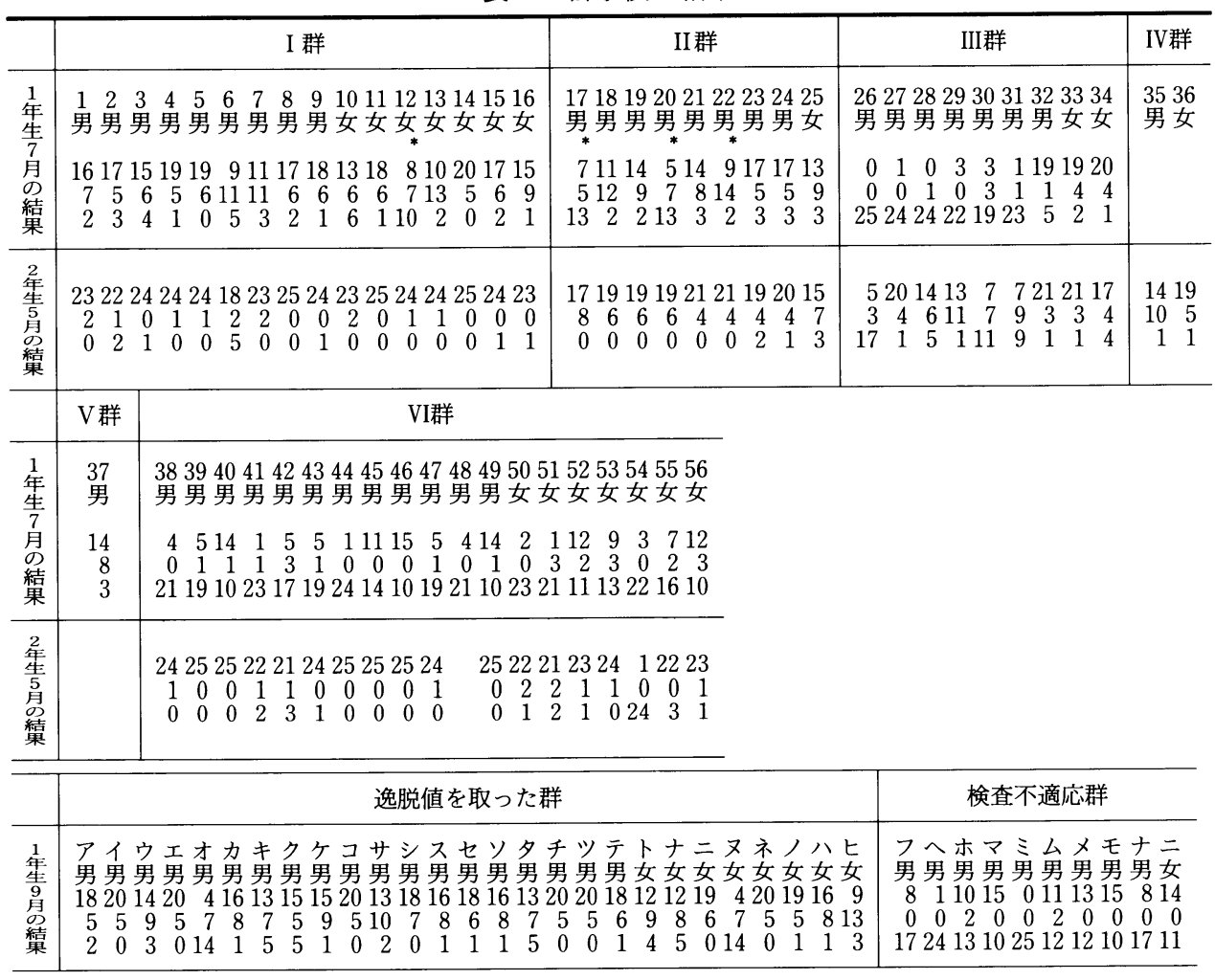

結果の読み方は [正答数・ラダ行音の誤り数・その他の誤り数または無答].したがって, 16.7.2 ならば 正答 16 , ラダ行音の誤り 7 , その他の誤りまたは無答 2 を意味する.

*は言語指導教室通級中の児童.

I 群 $\rightarrow 1$ 年生では逸脱值をとり 2 年生で逸脱值をとらなかった群

II 群 $\rightarrow 1$ 年生 2 年生とも逸脱值をとった群

III群 $\rightarrow 1$ 年生で逸脱值をとらなかったが 2 年生でとった群

IV群 $\rightarrow 2$ 年生で逸脱值をとつたが 1 年生の資料がない群

$\mathrm{V}$ 群 $\rightarrow 1$ 年生で逸脱值をとったが 2 年生の資料がない群

VI群 $\rightarrow 1$ 年生では検査不適応だったが, 2 年生では構音確立した群

う別な言い方に影響されると思われるデンシャを含め ドナルドダック, ヤサイサラダ, ドラエモン, ラクダ, ランドセルが該当する。この 6 語がそれぞれの全誤り に占める割合は未確立群 $31.1 \%$ (119 個中 37 個), 確 立群 $54.0 \%$ （87 個中 47 個）であり，1年生では未確 立群より確立群で誤りが目立つとした報告 ${ }^{12)} 2$ 年生 の時点でも追認した $\left(\chi^{2}=6.50, \mathrm{df}=1, \mathrm{P}<0.05\right.$, 表 3 ).

便宜的にその他の誤りが 10 以上あり, かつラダ行音 の誤りが逸脱值をとらなかった子どもを検查不適応児 と考えると, 1 年生の 7 月で $4.8 \%$ (被検児 516 人に 35 男, 36 女を加えた 518 人中 25 人), 9 月で $1.9 \%$ (531 人中 10 人), 2 年生の 5 月では $0.2 \%$ (518 人中
1人）の出現率であった（表 4$).$

語内位置と誤答の関係については，文献 $2 ， 3$ と一 致しなかった (表 5 )。1 検查語あたり語頭では平均ラ 行 9.7 , ダ行 1.5 , 語中尾ではラ行 5.8 , 夕゙行 5.3 誤つ た。この限りでは先行研究を支持する結果だが，デン シャをダ行音検査語と考えて語頭のダ行音に加えると 平均 7.6 にもなってしまう。語頭のラ行音にしてもロ ボットとロケットをぬかせば平均 3.5 にしかならな い. センロも含め, 詔答率には検査語の難易度が語内 位置より大きく影響している．ドラエモンという誤答 の少ない語があるが，それでもラダ行音混在語では平 均 14.0 の誤答率で他の検査語に比べ誤りが目立った $\left(\chi^{2}=31.79, \mathrm{df}=1, \mathrm{P}<0.01\right)$. 
表 3 誤答分析 ( 2 年生の 5 月)

\begin{tabular}{|c|c|c|}
\hline & 未確立 (II, III, IV)群 & 確立群 ( I 群) \\
\hline だんご & $2(1.83)$ & 0 \\
\hline らっぱ & $1(0.92)$ & 0 \\
\hline らあめん & $3(2.75)$ & 0 \\
\hline からす & 0 & 0 \\
\hline かいだん & $1(0.92)$ & 0 \\
\hline くじら & $1(0.92)$ & 0 \\
\hline なみだ & $4(3.67)$ & $1(1.15)$ \\
\hline れもん & $3(2.75)$ & 0 \\
\hline れいぞうこ & $5(4.59)$ & $2(2.30)$ \\
\hline ふでばこ & $6(5.50)$ & $2(2.30)$ \\
\hline くれよん & $2(1.83)$ & 0 \\
\hline ゆでたまご & $4(3.67)$ & $4(4.60)$ \\
\hline ろほっと & $13(11.93)$ & $8(9.20)$ \\
\hline ろけっと & $14(12.84)$ & $9(10.34)$ \\
\hline どうなつ & $1(0.92)$ & 0 \\
\hline じどうしゃ & $4(3.67)$ & $1(1.15)$ \\
\hline ぶどう & $5(4.59)$ & 0 \\
\hline めろん & $5(4.59)$ & 0 \\
\hline せんろ & $8(7.34)$ & $13(14.94)$ \\
\hline どなるどだっく & $7(6.42)$ & $17(19.54)$ \\
\hline やさいさらだ & $8(7.34)$ & $6(6.90)$ \\
\hline どらえもん & $3(2.75)$ & 0 \\
\hline らくだ & $7(6.42)$ & $2(2.29)$ \\
\hline らんどせる & $5(4.59)$ & $9(10.34)$ \\
\hline でんしゃ & $7(6.42)$ & $13(14.94)$ \\
\hline
\end{tabular}

カッコ内は各群の全誤答数にしめる割合（\%)

表 4 検查不適応の児童

\begin{tabular}{lccl}
\hline & 1 年 7 月 & 1 年 9 月 & 2 年 5 月 \\
\hline 検査不適応児童数 & 25 人 & 10 人 & 1 人 \\
出 現 率 & $4.8 \%$ & $1.9 \%$ & $0.2 \%$ \\
\hline
\end{tabular}

\section{考 察}

1 年生から 2 年生にかけて逸脱值は 5 から 3 に変化 した．全体として構音確立が進んだと考えられる。

1 年生のとき文字の習熟がこの検査を受けるに十分 ではなかったため回答数が少なく, したがって含まれ る誤答率も少なく逸脱值をとらなかったIII群（1 年生 のとき逸脱值をとらなかった 32 男, 33 女, 34 女を除 く）が浮かび上がってきたことが注目される。

1 年生 7 月で $5.0 \%$ 子どもが逸脱值をとり， 9 月 で $5.1 \%$ \%っったが, 検査不適応児の中にも未確立児 は含まれており，実際はこれらの出現率をやや上回る
表 5 詔答分析 ( 2 年生の 5 月)

\begin{tabular}{|c|c|c|c|c|}
\hline & & 誤答数 & 合計 & $\begin{array}{l}1 \text { 語あた } \\
\text { 誤答数 }\end{array}$ \\
\hline \multirow[t]{2}{*}{ 語頭 d } & だんご & 2 & & \\
\hline & どうなつ & 1 & 3 & 1.5 \\
\hline \multirow[t]{6}{*}{ 語頭 r } & らっぱ & 1 & & \\
\hline & らあめん & 3 & & \\
\hline & れもん & 3 & & \\
\hline & れいぞうこ & 7 & & \\
\hline & ろほっと & 21 & & \\
\hline & ろけっと & 23 & 58 & 9.7 \\
\hline \multirow[t]{6}{*}{ 語中尾 d } & かいだん & 1 & & \\
\hline & なみだ & 5 & & \\
\hline & ふでばこ & 8 & & \\
\hline & ゆでたまご & 8 & & \\
\hline & じどうしゃ & 5 & & \\
\hline & ぶどう & 5 & 32 & 5.3 \\
\hline \multirow[t]{5}{*}{ 語中尾 r } & からす & 0 & & \\
\hline & くじら & 1 & & \\
\hline & くれよん & 2 & & \\
\hline & めろん & 5 & & \\
\hline & せんろ & 21 & 29 & 5.8 \\
\hline \multirow[t]{6}{*}{ 混在語 } & どなるどだっく & 24 & & \\
\hline & やさいさらだ & 14 & & \\
\hline & どらえもん & 3 & & \\
\hline & らくだ & 9 & & \\
\hline & らんどせる & 14 & & \\
\hline & でんしゃ & 20 & 84 & 14.0 \\
\hline
\end{tabular}

と考えられる.

7 月と 9 月で変化がないのは, 7 月の時点で逸脱値 をとったうちの何パーセントかはすでに構音確立した ものの, 検查不適応児のうち一定数が 9 月の時点で新 たに適応できるようになり，相殺されたためと考えら れる.

7 月の検查に適応できなかった 25 人(転校した 1 人 を除く）のうち 2 年生になっても構音確立できていな かった子どもは 8 人 (32.0\%) いた。この結果から推 測すると 9 月時点で検查に不適応だった 10 人のうち 少なくとも 3 人程度は構音未確立と考えられる. 逸脱 值をとった 27 人に推測された 3 人を加え, 30 人前後 が未確立と思われ， 1 年生の 9 月における出現率は $5.6 \%$ 前後と推測される.

1 年生のときは構音確立していたが 2 年生になって 崩れたという子どもは，いてもごくわずかであるはず なので, III群, IV群の子どもは 1 年生のときにも構音 
表 6 小学校入学前後におけるラダ行音の構音未確立児の出現率

\begin{tabular}{llll}
\hline \multicolumn{1}{c}{ 検査時期 } & \multicolumn{1}{c}{ 出現率 } & 判定方法 \\
\hline 就学時健康診断時 5$)$ & $9 \%$ & $(592$ 人中 54 名 $)$ & 聴覚判定 \\
小学校 1 年生 7 月 & $7 \%+\alpha$ & $(516$ 人中 32 人 +数人) & 書字検査 \\
小学校 1 年生 9 月 & $6 \%$ & $(531$ 人中 27 人前後 $)$ & 書字検査 \\
小学校 2 年生 5 月 & $3.9 \%$ & $(518$ 人中 20 人) & 書字検查 \\
\hline
\end{tabular}

確立していなかったと考えられる。この 11 人を I , II， $\mathrm{V}$ 群の 26 人に加え， 518 人中 $37(7.1 \%)$ 人が未確立 だったことになる．また， 1 年生の時には検查不適応 で 2 年生になって逸脱值をとらなかった子ども (VI群) の中には, 書字の習熟不足のため構音確立していたも のの検査不適応だった子ども， 1 年の間に構音確立し たと考えられる子どもの 2 群が一定割合で混在してい ると予想される。したがって， 1 年生の 7 月における 出現率は $7.1 \%+\alpha$ と考えられる.

2 年生の 5 月では検査不適応児の出現率は $0.2 \%$ （518人中 1 人）であり, 出現率 $3.9 \%$ は十分信頼性が ある。

32 男, 33 女, 34 女の 3 人は 1 年生のときは逸脱值を とらず, 2 年生になってとった. はっきりは判らない が, 構音確立していたのが崩れたと考えるより, 確立 していなかったのにたまたま逸脱値をとらなかった例 外と考える方が妥当であると思われる.

まとめると, 小学校入学前後にかけてのラダ行音の 構音未確立児の出現率は, 表 6 のようになる.

誤り方の質的違いは大塚 ${ }^{12)}$ を追認した。確立群(確立 間際の子どもを含む) では聴覚弁別ができているが, 未確立群では聴覚弁別も未確立であり ${ }^{6)}$, 内的判断基 準ができていないためあてずっぼうで答えることが多 く, 単語間の難易度の違いが無視されてしまう. 確立 群ではやさしい語は内的判断基準に照らして誤らない が, 混在語ではラダ行音が相互干涉し, 目立つと考え られる.そして，この相互干涉から解放されたときが 完全に構音確立したときと考えられる。

ロボット，ロケットは未確立群，確立群ともに誤り が目立った。これは相互干涉では説明できない。促音 を含むと誤りやすいのかも知れないが，ラッパでは該 当しない. 閉鎖子音が後続すると影響を受けるのかも しれない. センロも説明がつかなかった。

日本語の/r/は「一般には語頭に起こる場合だけ [1] となり，語中でははじき音 (flap) $[\mathrm{r}]$ と呼ばれる，1 回振動のふるえ音として現れる.しかし, 日本語の[1] は英語の [1] よりもっと後方（硬口蓋の辺り）で調音

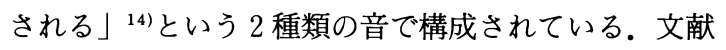

2,3 はこの構音操作上の違いに原因を求めている.

本報告が異なる結果を得た原因は検査語の違いと思 われる。文献 2 では語頭はラダ行音 5 , リ 1 を, 語中 尾はラダ行音 5 , リル 6 を, 文献 3 では語頭でラダ 9 , リル 0 を, 語中尾でラダ行音 20 , リル 15 を使ってい る.しかし, リル音とデヅ音は相互干渉しないからラ ダ行音に比べ誤りは少ない(4)ので, 語中尾で $/ \mathrm{d} / \rightarrow / \mathrm{r} /$ が目立ち, 相対的に語頭で $/ \mathrm{r} / \rightarrow / \mathrm{d} /$ が目立つ結果にな ったとも考えられる．語内位置よりラダ行音の相互干 渉がより影響すると思われた。

ラ行ダ行音を考えるとき，ラダ行音とリル音ヂヅ音 は区別が必要であると思われた.

\section{おわりに}

ラダ行音を混同する子どもたちはひとつの音に 2 系 統の文字が存在していると考えており，誤ったときな ぜそれが誤りなのか「ラはこっちの字だよ」と担任に 訂正されても理解できない. 構音だけならまだしも䛊 りが明白にわかる書字にもでるので, 毎日の勉強で悩 まなければならず, 精神的負担は大きいと思われる。

誤答分析により構音確立の予測ができれば，遅れる であろう子どもだけあらかじめ選別して早期指導する ことが可能になろう.

\section{文献}

1）船山美奈子, 阿部雅子, 加藤正子, 他：構音検査 法に関する追加報告. 音声言語医学, $30 ； 285-292$, 1989.

2) 中西靖子, 大和田健次郎, 藤田紀子 : 構音検査と その結果に関する考察. 東京学芸大学特殊教育研 究施設報告 1.1972 .

3）馬瀬良雄：幼稚園児の発音の実態一 4 歳児の場合 一. 音声の研究, $13 ； 277-296,1967$.

4）大塚 登：ラダ行音の誤りについての研究一渋川 市就学時健康診断言語検査の結果報告一. 聴覚言 語障害, $20 ； 29-33 ， 1991$.

5）細谷文雄：/s/に構音の誤りのある機能的構音障 害児の音声知覚について, 聴能言語学研究, 10 ; 
1-7, 1993.

6) 大塚 登：ラダ行音を誤る子どもの聴覚弁別能に ついての研究. 聴覚言語障害, $21 ； 143-153,1993$.

7）松下 淑, 早川清子 ; 語音弁別学習と構音の獲得. 聴覚言語障害, 4:157-163, 1975 .

8）床井明子，岡崎恵子： $/ \mathrm{r} /$ おび $/ \mathrm{s} /$ における語音 弁別力の発達と構音の獲得. 第 22 回日本聴能言語 学会学術講演会予稿集, 55, 1996.

9）市川季佐子, 久保田功, 城野明子, 他：機能的構 音障害症例の統計. 音声言語医学, $33: 101-102$, 1992.

10）神尾昭雄, 外池滋生：言い間違いの言語学. 言語 障害と言語理論 (今井邦彦編), 大修館書店, 東京, 271 308 頁, 1979 .
11）大塚 登：書字にみられたラダ行音の誤りについ ての研究. 聴覚言語障害, $20 ； 69-74,1991$.

12）大塚 登：ラダ行音を誤る児童の追跡調査一構音 指導の適応時期について一, 聴覚言語障害, 23 ： 57-64, 1994.

13）田中恒雄：新・統計のまとめ方つかい方，医歯薬 出版, 東京, 58-59 頁, 1975 .

14）柴谷方良, 影山太郎, 田守育啓 : 言語の構造一理 論と分析一. くろし抢出版，東京， 1981.

別刷請求先：干 377 渋川市並木町 681-2

渋川市立北小学校

大塚 登 